\title{
Pengaruh Biosin dan Ekstrak Cente terhadap Perkembangan Aphis glycines (Homoptera : Aphididae)
}

\author{
Hamoto, D. Koswanudin, dan A.N. Ardivinata
}

Balai Besar Penelitian dan Pengembangan Bioteknologi dan Sumberdạa Genctik Pertanian

J1. Tentara Pelajar $3 \$$ Bogor 16114

\begin{abstract}
A srudy was conducted at Enginering of Protcin and Immunology Division, Research Institure for Agricultural Biotechnology and Genetic Resources Bogor during 2000, to determine the effect of Biosin and Lantana amara seed exrracts on developmen of Aphis ghints. A completely randomized design was used with four replications. Treatment consisted of three concentrations of Bbiosirt and rwo concentrations of $L$ camard seed extracts and untreated (control). Thirty davs ofd sorbean plant in plastic pots were applied according to its treatments. Biosin and L. camara seed extracts were used as folar spray: Volume of spray solution was ${ }^{-} .5$ $\mathrm{ml} /$ pot. Half an hour after application, soybean plants were infested by 20 third instar A. 2fivites each pot. The result showed that Biosin and L. camara sced extracts decreased the development of $A$. gh whes populations, especialy Biosin $8 \%$ and $L$ camara seed exracts $0.4 \%$.
\end{abstract}

Key word: Biosin, Lemtaris camara, Aphis ghames.

\section{PENDAHULUAN}

Kedelai merupakan salah satu tanaman palawija yang mempunyai arri ekonomi yang penting baik sebagai bahan pangan maupun sebagai pakan ternak. Selama lima tahun terakhir ratarata produksi nasional kedelai berkisar antara $1192 \mathrm{~kg} / \mathrm{ha}$ hingga $1234 \mathrm{~kg} / \mathrm{ha}$ (Biro Pusat Statistik, 2002). Produksi ini relatif lebih rendah bila dibandingkan dengan potensi hasil yang dapat dicapai. Rendahnya hasil ini antara lain disebabkan : benih unggul tidak mencukupi, mutu benih kurang baik, lahan kurang sesuai, sarana produksi kurang, serta adanya serangan hama penyakit. Salah saru hama yang sering menyerang tanaman kedelai adalah Aplis glycines (Homoptera : Aphididac). A. gycines menyerang pucuk tanaman dan daundaun muda (Harnoto ef al, 1985). Hama ini juga menyebabkan kerusakan tanaman kedelai secara tidak langsung, yaitu sebagai vektor virus mosaik kedelai, virus kerdil kedelai, virus kacang mosaik, virus mosaik kuning kedelai (Tantera ef al., 1985),

Untuk mengatasi serangan A. glycines dan hama-hama kedelai lainnya, petani sering menggunakan insektisida sintctik. Hal ini disebabkan caracara lain yang lebih murah dan aman terhadap lingkungan belum banyak diperoleh keterangan. Akan tetapi penggunaan insektisida yang tidak bijaksana dapat menimbulkan pengaruh samping yang tidak diinginkan seperti timbulnya resistensi serangga hama sasaran, resurgensi, 
terbunuhnya musuh-musuh alami dan terbunuhnya serangga berguna lainnya serta pencemaran lingkungan lainnya (Palm et al., 1970). Untuk mengurangi pengaruh samping yang ditimbulkan oleh insektisida sintetik, maka perlu dicari cara-cara pengendalian lain yang lebih aman terhadap lingkungan. Salah satu alternatif untuk mengurangi penggunaan insektisida sintetik adalah dengan insektisida nabati. Dari hasil-hasil penelitian menunjukkan bahwa insektisida nabati toksik terhadap serangga hama (Balfas, 1994; Prijono dan Hassan, 1994; Harnoto et al., 1997; Harnoto et al., 1999a).

Penelitian ini bertujuan untuk mengetahui pengaruh penggunaan biosin dan ekstrak cente terhadap perkembangan populasi A. ghaines pada tanaman kedelai di rumah kaca.

\section{BAHAN DAN METODE}

Percobaan dilaksanakan di rumah kaca Kelti RPI Balai Penelitian Bioteknologi dan Sumberdaya Genetik Pertanian pada tahun 2000. Rancangan percobaan yang digunakan acak lengkap dengan tujuh perlakuan. Seciap perlakuan diulang empat kali. Sebagai perlakuan adalah 1. Biosin konsentrasi $2 \%$, 2. Biosin konsentrasi 4\%, 3. Biosin konsentrasi $6 \%, 4$. Biosin konsentrasi $8 \%$, 5. Ekstrak cente konsentrasi $0,2 \%$, 6. Ekstrak cente konsentrasi $0,4 \%$ dan kontrol (pembanding).

Tanaman kedelai yang digunakan disiapkan di rumah kaca dengan cara menanam benih kedelai varietas Wilis sebanyak 2 biji per pot. Pot yang digunakan untuk percobaan ini berdiameter $10 \mathrm{~cm}$ dengan tinggi $18 \mathrm{~cm}$. Sedangkan A. glycines yang digunakan diperoleh dari lapangan, kemudian diperbanyak di rumah kaca dengan menggunakan tanaman kedelai sebagai pakannya. Pada waktu tanaman kedelai berumur 30 hari setelah tanam, disemprot dengan biosin dan ekstrak cente sesuai dengan perlakuan masing-masing. Lntuk kontrol tanaman kedelai disemprot dengan air. Kurang lebih setengah jam setelah penyemprotan, tanaman kedelai diinfestasi A. glyines sebanyak 20 ekor setiap perlakuan per ulangan. Setelah itu tanaman kedelai disungkup dengan milarsit, yang bagian atasnya ditutup dengan kain batis berwarna putih.

Untuk mengetahui pengaruh biosin dan ekstrak cente dilakukan pengamatan populasi $A$. ghintes pada waktu 1 , $2,3,8$ dan 15 hari sctelah infestasi.

\section{HASIL}

Hasil pengamatan terhadap populasi A. glycines pada waktu satu hari setelah infestasi menunjukkan bahwa populasi A. glycines pada perlakuan biosin berkisar antara 14,25 ekor hingga 20 ekor. Populasi $A, g /$ cines pada perlakuan ekstrak cente berkisar antara 11 ekor hingga 20 ekor, sedang populasi $A$. glyines pada kontrol sebanyak 20 ekor (Tabel 1). Perlakuan biosin konsentrasi $8 \%$ dan perlakuan ekstrak cente konsentrasi $0,4 \%$ masing-masing berbeda nyata 
dengan kontrol. Sedangkan perlakuan biosin konsentrasi 2\% hingga $6 \%$ dan perlakuan ekstrak cente konsentrasi $0,2 \%$ masing-masing tidak berbeda nyata dengan kontrol (Tabel 1). Dengan demikian pada waktu satu hari setelah infestasi hanya perlakuan biosin konsentrasi $8 \%$ dan perlakuan ekstrak cente konsentrasi $0,4 \%$ yang dapat menekan populasi A. ghizines.

Hasil pengamatan pada waktu dua hari setelah infestasi menunjukkan bahwa populasi $A$. glyines pada perlakuan biosin berkisar antara 6,25 ekor higga 16,5 ekor/ perlakuan. Populasi A. glyines pada perlakuan ekstrak cente berkisar antara 5,75 ekor hingga 17,5 ekor, sedangkan populasi A. glyines pada kontrol sebanyak 20,75 ekor (Tabel 1). Perlakuan biosin konsentrasi $2 \%$, biosin konsentrasi $4 \%$, biosin konsentrasi $6 \%$, biosin konsentrasi $8 \%$, dan perlakuan ekstrak cente konsentrasi $0,4 \%$ masingmasing berbeda nyata dengan kontrol (Tabel 1). Dengan demikian perlakuan biosin konsentrasi $2 \%$, biosin konsentrasi $4 \%$, biosin konsentrasi $6 \%$, biosin konsentrasi $8 \%$ dan perlakuan ekstrak cente konsentrasi $0,4 \%$ yang masing- masing dapat menekan perkembangan A. glycines.

Hasil pengamatan pada waktu tiga hari setelah infestasi menunjukkan bahwa populasi A. glycines pada perlakuan biosin konsentrasi $2 \%$ hingga konsentrasi $8 \%$ berkisar antara 8,25 ekor hingga 19,25 ekor (label 2). Populasi A. ghines pada perlakuan cente konsentrasi $0,2 \%$ dan konsentrasi $0,4 \%$ berturut-turut adalah 6,50 ekor dan 24 ekor, sedangkan populasi A. 2/uines pada kontrol adalah 31,25 ekor (Tabel 2). Perlakuan biosin konsentrasi $2 \%$, biosin konsentrasi $4 \%$, biosin konsentrasi $6 \%$, biosin konsentrasi $8 \%$, ekstrak cente konsentrasi $0,2 \%$ dan perlakuan ekstrak cente konsentrasi $0,4 \%$ masing-masing berbeda nyata dengan kontrol (Tabel 2). Dengan demikian perlakuan biosin konsentrasi $2 \%$, biosin konsentrasi $4 \%$, biosin konsentrasi $6 \%$ dan biosin konsentrasi $8 \%$ masing-masing dapat menckan perkembangan populasi $A$. glyines. Begitu pula perlakuan ekstrak cente konsentrasi $0,2 \%$ dan ekstrak cente konsentrasi $0,4 \%$ masing-masing dapat menekan populasi A. glvines.

Tabel 1. Pulasi A. glycines (ekor) pada waktu 1 dan 2 hsi (hari setelah infestasi\}.

\begin{tabular}{lcc}
\hline \hline \multirow{2}{*}{ Perlakuan } & \multicolumn{2}{c}{ Populasi A. glycines (ekor) } \\
\cline { 2 - 3 } & $1 \mathrm{hsi}$ & $2 \mathrm{hsi}$ \\
\hline Biosin $2 \%$ & $20,00 \mathrm{c}$ 1) & $16,00 \mathrm{~b}^{11}$ \\
Biosin $4 \%$ & $20,00 \mathrm{c}$ & $16,50 \mathrm{~b}$ \\
Biosin $6 \%$ & $20,00 \mathrm{c}$ & $6,75 \mathrm{a}$ \\
Biosin $8 \%$ & $14,25 \mathrm{~b}$ & $6,25 \mathrm{a}$ \\
Cente $0,2 \%$ & $20,00 \mathrm{c}$ & $17,50 \mathrm{bc}$ \\
Cente $0.4 \%$ & $11,00 \mathrm{a}$ & $5,75 \mathrm{a}$ \\
Kontrol & $20,00 \mathrm{c}$ & $20,75 \mathrm{c}$ \\
\hline
\end{tabular}

"Angka-angka pada lajur yang sama yang diikuti oleh huruf yang sama adalah tidak berbeda nyata menurut uji beda nyata jujur (HSD) $5 \%$. 
Tabel 2. Populasi A. glycines pada waktu 3 dan 8 hsi (hari setelah infestasi).

\begin{tabular}{lcc}
\hline \hline \multirow{2}{*}{ Perlakuan } & \multicolumn{2}{c}{ Populasi A. giycines (ekor) } \\
\cline { 2 - 3 } & $3 \mathrm{hsi}$ & $8 \mathrm{hsi}$ \\
\hline Biosin $2 \%$ & $19,25 \mathrm{c}^{11}$ & $44,00 \mathrm{~b}^{11}$ \\
Biosin $4 \%$ & $17,00 \mathrm{c}$ & $29,75 \mathrm{bc}$ \\
Biosin $6 \%$ & $13,25 \mathrm{~d}$ & $23,00 \mathrm{~cd}$ \\
Biosin $8 \%$ & $8,25 \mathrm{e}$ & $2,75 \mathrm{e}$ \\
Ekstrak cente $0,2 \%$ & $24,00 \mathrm{~b}$ & $40,00 \mathrm{~b}$ \\
Ekstrak cente $0,4 \%$ & $6,50 \mathrm{f}$ & $12,75 \mathrm{~d}$ \\
Kontrol & $31,25 \mathrm{a}$ & $81,75 \mathrm{a}$ \\
\hline
\end{tabular}

1)Angka-angka pada lajur yang sama yang diikuti oleh huruf yang sama adalah tidak berbeda nyata menurut uji beda nyata jujur (HSD) $5 \%$.

Hasil pengamatan pada waktu delapan hari setelah infestasi menunjukkan bahwa populasi $A$. glycines pada perlakuan biosin konsentrasi $2 \%$, biosin konsentrasi $4 \%$, biosin konsentrasi $6 \%$ dan biosin konsentrasi $8 \%$ berkisar antara 2,75 ekor hingga 44 ekor (Tabel 2). Populasi A. glycines pada perlakuan ekstrak cente konsentrasi $0,2 \%$ dan ekstrak cente konsentrasi $0,4 \%$ berturut-turut 12,75 ekor dan 40 ekor (Tabel 2). Sedangkan populasi A. glyines pada kontrol sebanyak 81,75 ekor (Tabel 2). Perlakuan biosin konsentrasi $2 \%$, biosin konsentrasi $4 \%$, biosin konsentrasi $6 \%$ dan biosin konsentrasi $8 \%$ masingmasing berbeda nyata dengan kontrol. Perlakuan ekstrak ccnte konsentrasi $0,2 \%$ dan ekstrak cente konsentrasi $0,4 \%$ masing-masing juga berbeda nyata dengan kontrol. Dengan demikian perlakuan biosin konsentrasi $2 \%$, biosin konsentrasi $4 \%$, biosin konsentrasi $6 \%$ dan perlakuan biosin konsentrasi $8 \%$ masing-masing dapat menekan perkembangan populasi $A$. glycines. Begitu pula perlakuan ekstrak cente konsentrasi $0,2 \%$ dan ekstrak cente konsentrasi
$0,4 \%$ masing-masing dapat menckan perkembangan populasi $A$ glyines.

Hasil pengamatan pada wakru 15 hari setelah infestasi menunjukkan bahwa populasi A. glycines pada perlakuan biosin konsentrasi $2 \%$, biosin konsentrasi $4 \%$, biosin konsentrasi $6 \%$ dan biosin konsentrasi $8 \%$ berkisar antara 78,25 ekor hingga 195 ekor. Populasi $A$. gbrimes pada perlakuan ekstrak cente konsentrasi $0,2 \%$ dan ekstrak cente konsentrasi $0,4 \%$ berturut-turut adalah 160,25 ekor dan 68,25 ekor (Tabel 3). Sedangkan populasi A. g/vines pada kontrol adalah sebanyak 551,50 (Tabel 3). Menurut uji beda nyata jujur (HSD) pada taraf $5 \%$ menunjukkan bahwa perlakuan biosin konsentrasi $2 \%$, biosin konsentrasi $4 \%$, biosin konsentrasi $6 \%$ dan biosin konsentrasi $8 \%$ masingmasing berbeda nyata dengan kontrol (Tabel 3). Dengan demikian perlakuan biosin konsentrasi $2 \%$, biosin konsentrasi $4 \%$, biosin konsentrasi $6 \%$ dan biosin konsentrasi $8 \%$ masing-masing dapat menckan populasi $A$. gycines. Menurut uji beda nyata jujur (HSD) pada taraf $5 \%$ menunjukkan bahwa perlakuan ekstrak cente konsentrasi $0,2 \%$ 
Tabel 3. Populasi A. giycines pada waktu 15 hsi (hari setelah infestasi)

\begin{tabular}{rlc}
\hline \hline No. & Perlakuan & Populasi A. glycines (ekor) \\
\hline 1. & Biosin $2 \%$ & $195,00 \mathrm{~b}$ \\
2. & Biosin $4 \%$ & $179,50 \mathrm{~b}$ \\
3. Biosin $6 \%$ & $112,50 \mathrm{c}$ \\
4. & Biosin $8 \%$ & $78,25 \mathrm{~d}$ \\
5. Ekstrak cente $0,2 \%$ & $160,25 \mathrm{~b}$ \\
6. Ekstrak cente $0,4 \%$ & $68,25 \mathrm{~d}$ \\
7. & Kontrol & $551,50 \mathrm{a}$ \\
\hline
\end{tabular}

"Angka-angka pada lajur yang sama yang dikuti oleh huruf yang sama adalah tidak berbeda nyata menurut uji beda nyata jujur (HSD) $5 \%$

dan ekstrak cente konsentrasi $0,4 \%$ masing-masing berbeda nyata dengan kontrol (Tabel 3). Dengan demikian perlakuan ekstrak cente konsentrasi $0,2 \%$ dan ekstrak cente konsentrasi $0,4 \%$ masing-masing dapat menekan populasi A. glycines.

\section{PEMBAHASAN}

Populasi A. ghines pada percobaan ini merupakan populasi satu spesies atau populasi spesies tunggal. Menurut Clark (1954) populasi spesies tunggal cenderung meningkat karena faktor reproduksi dan populasi menurun karena faktor kematian. Tinggi dan rendahnya reproduksi dipengaruhi oleh faktor ekstrinsik dan faktor intrinsik (Dixon, 1987). Faktor ekstrinsik meliputi dua hal yaitu makanan dan temperatur.

Pada percobaan ini faktor tempetatur sama untuk semua perlakuan, yaitu temperatur di rumah kaca. Sedangkan faktor makanan pada dasarnya sama, vaitu tanaman kedelai. Pcrbedaan terletak pada tanaman kedelai ada yang mendapatkan penyemprotan biosin dengan beberapa konsentrasi, ada tanaman kedelai yang mendapatkan penyemprotan ekstrak cente dengan dua konsentrasi dan ada pula tanaman kedelai yang hanya mendapatkan penyemprotan air saja.

Populasi 4. ghrines pada perlakuan biosin dan ekstrak cente lebih rendah dari pada kontrol. Hal ini disebabkan biosin dan ekstrak cente mengandung bahan yang bersifat racun (toksik). Biosin terbuat dari bahan yang berasal dari tumbuhan yairu Deris elliptica. Bahan ini dapat digunakan untuk mengendalikan serangga hama (Koemiati of al., 1994: Kemala dan Mauludi, 1994: Direktorar Bina Perlidungan Tanaman Perkebunan, 1994 dan Kardinan et al., 1998). Senyawa kimia yang bersifat racun vang diperoleh dari $D$. elliptica antara lain adalah rotenon (Koerniati et al, 1994). Rotenon bekerja sebagai racun kontak dan racun perut (Fernald and Shepard, 1955). Biosin yang berkonsentrasi lebih tinggi pengaruhnya terhadap kematian A. ghithes lebih tinggi dan efek residunya lebih lama dari pada biosin yang berkonsentrasi lebih rendah.

Ekstrak cente dapat menekan perkembangan populasi $A$. gicines karena mengandung senyawa kimia yang bersifat racun, yaitu asam lantanin atau 
asam triterphen terutama lantaden $A$ (Seawright, 1982). Hasil-hasil penelitian sebelumnya menunjukkan bahwa ekstrak cente bersifat racun terhadap larva penggerek polong Ettiella zinkenella (Harnoto et al., 1999b), bersifat racun terhadap larva Spodoptera litura (Harnoto et al., 2000; Santoso dan Prasetyono, 2000) dan bersifat racun terhadap larva penggerek polong kacang hijau Marwa restulalis (Koswanudin et al, 2000). Menurut Setiawati et al. (1986) daun cente yang dikeringkan bersifat racun terhadap Phthorimaea operzulella. Ekstrak cente pada konsentrasi tinggi lebih beracun dan mempunyai pengaruh residu yang lebih lama dari pada ekstrak cente yang berkonsentrasi lebih rendah.

\section{KESIMPULAN}

1. Perlakuan biosin pada konsentrasi $2 \%$ hingga $8 \%$ serta ekstrak cente pada konsentrasi $0,2 \%$ hingga $0,4 \%$ dapat menghambat perkembangan populasi $A$, gbines.

2. Populasi A. glyines pada perlakuan biosin konsentrasi $8 \%$ lebih rendah daripada perlakuan biosin lainnya.

3. Populasi A. g/rines pada perlakuan ekstrak cente konsentrasi $0,4 \%$ lebih rendah daripada perlakuan ekstrak cente konsentrasi $0,2 \%$.

\section{PUSTAKA}

Balfas, R. 1994. Pengaruh ekstrak air dan etanol biji mimba rerhadap mortalitas dan pertumbuhan ulat pemakan daun handeuleum Doleschallia polibete. Prosiding Seminar Hasil Penelitian Dalam Rangka Pemantaatan Pestisida Nabati. Balai
Penclirian Tanaman Rempah dan Obar. Bogor. 203-207 p.

Biro Pusat Statistik. 2002. Statistik Indonesia 2001. Jakarra.

Clark, G.1. 1954. Element of Ecology. John Wiley \& Sons, Inc. Toppan Company, Ltd. Tokyo, Japan. 560 pp.

Direkrorat Bina Perlindungan Tanaman Perkebunan 1994. Lipaya pemanfaatan pestisida nabati dalam rangka penerapan sistem pengendalian hama terpadu. Prosiding Seminat Hasil Penelitian Dalam Rangka Pemanfaatan Pestisida Nabati. Balai Penelirian Tanaman Rempah dan Obat Bogor. 279.285 p.

Dixon, A.F.G. 1987. Parthenogenetic reproduction and the rate of increase in Aphids, 269-287. Dalam A.K . Minks and P. Harrewijn. Aphids, Their Biologr, Natural Enemies and Control.

Femald, H.T and H.H. Shepard. 1953. Applied Entomology: An Introduction Texrbook of Insects in Their Relation to Man. Mc Graw-Hill Book Company, Ine. The Maple Press Co, Jork. 385 pp.

Hamoto, A. Iqbal, $K$ Honma, A. Naito, dan K. Yamagishi. 1985. Hama Kedelai. 41-73. Delam Pusat Penelitian dan Pengembangan Tanaman Pangan, Balai Penelitian Tanaman Pangan Bogor dan JICA. Petunjuk Bergambar untuk Identifikasi Hama dan Penyakit Kedelai di Indonesia.

Hamoto, D. Koswanudin, dan A. Nugraha. $199^{-}$. Pengaruh ekstrak bij bengkuang dan biji nimba terhadap beberapa aspek biologi penggerek polong Etiella rimkenella. Prosiding Seminar Nasional Tantangan Entomologi pada Abad XXI. Bogor. 338 . $345 \mathrm{p}$.

Hamoto, D. Koswanudin, dan t. Nugnaha. 1999a. Pengaruh ekstrak temu hitam terhadap beberapa aspek biologi penggerek polong Etiella zinckenella (Lepidoptera: Prralidae), Prosiding Seminar Nasional Peranar Entomologi dalam Pengendalian Hama yang Ramah Lingkungan dan Ekonomis. PEI Cabang Bogor. 1:231-238.

Harnoto, D. Koswanudin, dan A. Nugraha. 1999b. Pengaruh ekstrak biji Lantana camara terhadap biologi Etiella sinkenella Treirschke. Penelitian Pertanian 18(2):34$38 \mathrm{p}$. 
Hamoto, D. Koswanudin, dan A. Nugraha. 2000. Pengaruh Ekstrak Biji Lantana camara terhadap beberapa aspek biologi Spodoptera litura (Lepidoptera noctuidac). Prosiding Forum Komunikasi Ilmiah Pemanfaatan Pestisida Nabati. Pusat Penelitian dan Pengembangan Tanaman Perkebunan. 133-139p.

Kardinan, 1998. Prospek penggunaan pestisida nabati di Indonesia. Jurnal Litbang Pertanian. XVII (1):1-8 p.

Kemala, S. dan L. Mauludi, 1994. Potensi sumberdaya dan permasalahan pengembangan pestisida nabai di Indonesia. Prosiding Seminar Hasil Penelitian Dalam Rangka Pemanfaatan Pestisida Nabati. Balai Penelitian Tanaman Rempah dan Obat. Bogor. 286-292 p.

Koermiati, S., M. Iskandar, dan Tarono. 1994. Plasma nuftah tanaman berkadar racun d Balittro. Prosiding Seminar Hasil Penelitian Dalam Rangka Pemanfaatan Pestisida Nabati. Balai Penelitian Tanaman Rempah dan Obat. Bogor. 241-247 p.

Koswanudin, D. dan Harnoto. 2000. Keefektifan ekstrak biji mimba (Azadirachta indica) terhadap pengisap polong kedelai Riplortus linearis. Prosiding Forum Komunikasi Ilmiah Pemanfaatan Pestisida Nabati. Bogor. 220-226p.

Palm, C.E., W. W. Dykstra, G. Ferguson, E. Hansberr, W.Y. Hayes, J.R.L.W.
Hazleton, J.C. Horsfall, E.F. Knipling, L.D. I each, R.L. Lovvorn, and G.A. Swanson. 1970. Insect Pest Management and Control. Principles of Plant and Animal Pest Control. 3:508 pp.

Privono, D. dan E. Hassan. 1994. Pengaruh ekstrak mimba (Avadirachra indiza) rerbadap perkembangan dan mortalitas Crovidolomia benotalis. Prosiding Seminar Hasil Penelitian Dalam Rangka Pemanfaatan Pestisida Nabati. Balai Penelitian Tanaman Rempah dan Obat. Bogor. 193-202 p.

Seawright, A.1. 1982. Chemical and plant poisons. Animal Health in Australia. 290 p.

Setiawat, W., S. Sastrosiswojo dan E. Safari. 1986. Penggunaan daun Lantana sp kering, sekam padi dan inscktisida unnuk pengendalian hama penggerek umbi kentang di dalam gudang pentimpanan. Buletin Penelitian Hortikulnura. XIV(1):611.

Tantera, .I. Machmud, Roechan, M. Sudjadi, X. Saleh, E. Soetarwo, K. Matsumoto, II. Iwaki, dan X. Iizuka. 1985. Penyakit kedelai 75-97. Dalam Pusat Penelitian dan Pengembangan Tanaman Pangan, Balai Penelitian Tanaman Pangan Bogor dan JIC.1. Perunjuk Bergambar untuk Identifikasi Hama dan Penyakit Kedelai di Indonesia. 